\title{
Pengaruh Karakteristik Peserta Didik terhadap Hasil Belajar di Sekolah Dasar
}

\author{
Riswanda \\ SD Negeri Pasirpanjang 03 \\ riswanda57@gmail.com
}

\section{Article History}

received $3 / 12 / 2020$

\begin{abstract}
One of the obstacles in teaching and learning activities in schools is the characteristics of students. Recognizing the characteristics of students is something that needs to be done by an educator. One of the cases that occurs in learning is the low interest in learning of students. This is a case that often occurs in learning at school. The Covid-19 pandemic has created new habits. Now almost everyone who is familiar with the gadgets used to be brave with its various applications, poses a dilemma: it is very useful on one side and dangerous on the other. Useful because all things starting from school children, doing homework, collecting assignments. Dangerous because it can cause addiction to children. Results Based on the literature review, the characteristics of students are: ethnicity, culture, social status, interests, cognitive development, prior knowledge, learning styles, motivation, emotional development, moral development, spiritual development and motor development. Constraints in general in learning activities, namely motivation and interest in learning.
\end{abstract}

Keywords: characteristics of students, learning outcomes, elementary school

\begin{abstract}
Abstrak
Salah satu kendala dalam kegiatan belajar mengajar di sekolah adalah karakteristik peserta didik. Mengenali karakteristik peserta didik merupakan hal yang perlu dilakukan oleh seorang pendidik. Salah satu kasus yang terjadi dalam pembelajaran yaitu rendahnya minat belajar peserta didik. Hal ini menjadi kasus yang sering terjadi dalam pembelajaran di sekolah. Pandemi Covid - 19 menimbulkan kebiasaan baru. Kini hampir semua orang akrab dengan gadget yang digunakan untuk daring dengan berbagai aplikasinya, menimbulkan dilema : sangat bermanfaat di satu sisi dan membahayakan di sisi lainnya. Bermanfaat karna semua urusan mulai dari anak sekolah, mengerjakan PR, mengumpulkan tugas. Membahayakan karna dapat menimbulkan kecanduan terhadap anak. Berdasarkan hasil kajian literature maka karakteristik Peserta Didik yaitu : etnik, kultural, status sosial, minat, perkembangan kognitif, pengetahuan awal, gaya belajar, motivasi, perkembangan emosi, perkembangan moral, perkembangan spiritual dan perkembangan motorik. Kendala secara umum pada kegiatan pembelajaran yaitu motivasi dan minat belajar.
\end{abstract}

Kata kunci: karakteristik peserta didik, hasil belajar, sekolah dasar

Social, Humanities, and Education Studies (SHEs): Conference Series https://jurnal.uns.ac.id/shes 


\section{PENDAHULUAN}

Salah satu kendala dalam kegiatan belajar mengajar di sekolah adalah karakteristik peserta didik. Karakteristik peserta didik terdiri atas : etnik, kultural, status sosial, minat, perkembangan kognitif, pengetahuan awal, gaya belajar, motivasi, perkembangan emosi, perkembangan moral, perkembangan spiritual dan perkembangan motorik, Mengenali karakteristik peserta didik merupakan hal yang perlu dilakukan oleh seorang pendidik. Salah satu kasus yang terjadi dalam pembelajaran yaitu rendahnya minat belajar peserta didik. Hal ini menjadi kasus yang sering terjadi dalam pembelajaran di sekolah.

Pandemi Covid - 19 menimbulkan kebiasaan baru. Kini hampir semua orang akrab dengan gadget yang digunakan untuk daring dengan berbagai aplikasinya, menimbulkan dilema : sangat bermanfaat di satu sisi dan membahayakan di sisi lainnya. Bermanfaat karna semua urusan mulai dari anak sekolah, mengerjakan PR, mengumpulkan tugas. Membahayakan karna dapat menimbulkan kecanduan terhadap anak

Berdasarkan kasus-kasus tersebut menunjukkan bahwa mengenali karakteristik peserta didik sangat penting. Hal ini perlu dilakukan untuk mengetahui hubungan karakteristik peserta didik dengan kebiasaan baru penggunaan gadget di masa pandemi Covid-19.

Pendidikan karakter adalah upaya mewujudkan generasi bangsa yang cerdas dan baik (smart and good citizenship) atau memiliki ahlak mulia dan berkepribadian Indonesia. Keberhasilan pendidikan karakter mengisyaratkan pembelajaran tidak serta merta dilihat dari pesepektif ranah kognitif saja melainkan bagaimana keseimbangan ranah kognitif, afektif, dan psikomotor yang muaranya adalah mewujudkan manusia seutuhnya. (I Wayan Eka Santika, 2020:3). Pendidikan karakter adalah sebuah usaha untuk menerapkan nilai-nilai agama, moral, etika pada peserta didik melalui ilmu pengetahuan, dibantu oleh orang tua, guru, serta masyarakat yang sangat penting dalam pembentukan dan perkembangan karakter peserta didik.Setiap anak memiliki potensi yang baik sejak lahir, namun potensi tersebut harus terus diasah dan disosialisasikan dengan baik agar karakter setiap anak terbentuk dan berkembang secara maksimal.Di zaman serba digital ini juga anak dengan mudahnya menggunakan media digital (Miftah Nurul Annisa, Ade Wiliah, Nia Rahmawati, 2020:2)

Guru merupakan tenaga pendidik yang berperan penting dalam kehidupan berbangsa dan bernegara. Pada jenjang pendidikan mulai dari pendidikan formal, pendidikan dasar, dan pendidikan menengah guru memiliki pengaruh bagi siswa siswi yang diajarkan dalam sebuah metode pembelajaran atau dalam hal berperilaku. Falsafah jawa mengatakan bahwa Guru merupakan singakatan dari "Digugu lan Ditiru", maka dari itu peran guru sangat besar dalam pembentukan pola pikir serta karakter anak didik (Riza Ayu Wulandari, Nyoman Ayu Nila Dewi, I Wayan Gede Lamopia, Ni Nyoman Wulan Antari, 2020:1)

\section{HASIL DAN PEMBAHASAN}

Pada bagian ini akan dibahas pokok bahasan, yaitu a) Ragam Karakteristik Peserta Didik, dan b) Karakteristik Peserta Didik yang sering menjadi masalah dalam pembelajaran secara umum.

\section{A) Ragam Karakteristik Peserta Didik}

\section{Etnik}

Negara Indonesia merupakan negara yang luas wilayahnya dan kaya akan etniknya. Namun berkat perkembangan alat transpotasi yang semakin modern, maka seolah tidak ada batas antar daerah/suku dan juga tidak ada kesulitan menuju daerah lain untuk bersekolah, sehingga dalam sekolah dan kelas tertentu 
terdapat multi etnik/suku bangsa, seperti dalam satu kelas kadang terdiri dari peserta didik etnik Jawa, Sunda, Madura, Minang, dan Bali, maupun etnik lainnya.

\section{Kultural}

Meskipun kita telah memiliki jargon Sumpah Pemuda yang mengakui bertumpah darah yang satu tanah air Indonesia, berbangsa yang satu bangsa Indonesia dan menjunjung bahasa persatuan bahasa Indonesia. Namun peserta didik kita sebagai anggota suatu masyarakat memiliki budaya tertentu dan sudah barang tentu menjadi pendukung budaya tersebut. Budaya yang ada di masyarakat kita sangatlah beragam, seperti kesenian, 56 kepercayaan, norma, kebiasaan, dan adat istiadat

\section{Status sosial}

Manusia diciptakan Tuhan dengan diberi rizki seperti berupa pekerjaan, kesehatan, kekayaan, kedudukan, dan penghasilan yang berbedabeda. Kondisi seperti ini juga melatar belakangi peserta didik yang ada pada suatu kelas atau sekolah kita. Peserta didik pada suatu kelas biasanya berasal dari status sosialekonomi yang berbeda-beda. Dilihat dari latar belakang pekerjaan orang tua, di kelas kita terdapat peserta didik yang orang tuanya wira usahawan, pegawai negeri, pedagang, petani, dan juga mungkin 57 menjadi buruh. Dilihat dari sisi jabatan orang tua,

\section{Minat}

Minat dapat diartikan suatu rasa lebih suka, rasa ketertarikan pada suatu hal atau aktivitas. Hurlock (1990: 114) menyatakan bahwa minat merupakan suatu sumber motivasi yang mendorong seseorang untuk melakukan kegiatan yang dipilinnya.

\section{Perkembangan kognitif}

Tingkat perkembangan kognitif yang dimiliki peserta didik akan mempengaruhi guru dalam memilih dan menggunakan pendekatan pembelajaran, metode, media, dan jenis evaluasi. Taman Kanak-kanak yang peserta didiknya sekitar berumur 5-6 tahun, sudah tentu berbeda pendekatan, metode, dan media yang digunakan ketika menghadapi peserta didik. Sekolah Dasar yang peserta didiknya berusia 711 tahun, dan peserta didik Sekolah Menengah Pertama yang usianya berkisar 1214 tahun dan juga peserta didik Sekolah Menengah Atas atau Sekolah Menengah Kejuruan, yang umumnya berusia 15-17 tahun

\section{Pengetahuan awal}

Kemampuan awal atau entry behavior menurut Ali (1984: 54) merupakan keadaan pengetahuan dan keterampilan yang harus dimiliki terlebih dahulu oleh peserta didik sebelum mempelajari pengetahuan atau keterampilan baru. Pengetahuan dan keterampilan yang harus dimiliki terlebih dahulu maksudnya adalah pengetahuan atau keterampilan yang lebih rendah dari apa yang akan dipelajari.

\section{Gaya belajar}

Gaya belajar menurut Masganti (2012: 49) didefinisikan sebagai cara yang cenderung dipilih seseorang untuk menerima informasi dari lingkungan dan memproses informasi tersebut. DePorter dan Hemacki dalam Masganti (2012; 49) gaya belajar adalah kombinasi dari cara menyerap, mengatur dan mengolah informasi. Dari dua pendapat tersebut dapat ditegaskan bahwa gaya belajar adalah cara yang cenderung dipilih/digunakan oleh peserta didik dalam menerima, mengatur, dan memproses informasi atau pesan dari komunikator/pemberi informasi. Gaya belajar peserta didik merupakan hal yang penting untuk 
diperhatikan dalam melakukan proses pembelajaran karena dapat mempengaruhi proses dan hasil belajarnya.

\section{Motivasi}

Motivasi telah banyak didefinisikan oleh para ahli, diantaranya oleh Wlodkowski (dalam Suciati, 1994:41) yaitu suatu kondisi yang menyebabkan atau menimbulkan perilaku tertentu, dan yang memberi arah dan ketahanan (persistence) pada tingkah laku tersebut. Motivasi kadang timbul dari dalam diri individu itu sendiri (motivasi instrinsik dan kadang motivasi itu muncul karena faktor dari luar dirinya sendiri (motivasi ekstrinsik)

\section{Perkembangan emosi}

Emosi telah banyak didefinisikan oleh para ahli, diantaranya Kartono dalam Sugihartono (2013: 20) mendefinisikan emosi sebagai tergugahnya perasaan yang disertai dengan perubahan-perubahan dalam tubuh, misalnya otot menegang, dan jantung berdebar. Dengan emosi peserta didik dapat merasakan senang/gembira, aman, semangat, bahkan sebaliknya peserta didik merasakan sedih, takut, dan sejenisnya.

\section{Perkembangan moral}

Perkembangan sosial menurut Hurlock, (1998: 250) adalah kemampuan anak untuk berinteraksi dengan lingkungannya, bagaimana anak tersebut memahami keadaan lingkungan dan mempengaruhinya dalam berperilaku baik kepada dirinya sendiri maupun kepada orang lain. Dari pernyataan ini dapat ditegaskan bahwa perkembangan sosial peserta didik merupakan kemampuan peserta didik untuk menyesuaikan diri terhadap norma-norma dan tradisi yang berlaku pada kelompok atau masyarakat, kemampuan untuk saling berkomunikasi dan kerja sama.

\section{Perkembangan spiritual}

Dalam kehidupan bermasyarakat termasuk masyarakat di lingkungan sekolah pasti mengenal moralitas, bahkan moralitas ini dijadikan sumber/acuan untuk menilai suatu tindakan atau perilaku karena moralitas memiliki kriteria nilai (value) yang berimplikasi pada takaran kualitatif, seperti: baik-buruk, benar-salah, pantastidak pantas, wajar-tidak wajar, layak-tidak layak, dan sejenisnya. Moralitas dalam diri peserta didik dapat tingkat yang paling rendah menuju ke tingkatan yang lebih tinggi seiring dengan kedewasaannya.

\section{Perkembangan motorik}

Salah satu faktor penting dalam perkembangan individu secara keseluruhan yang perlu dikenali dan dipahami pendidik adalah faktor perkembangan motorik peserta didiknya. Perkembangan motorik menurut Hurlock diartikan perkembangan gerakan jasmaniah melalui kegiatan pusat syaraf, urat syaraf, dan otot yang terkordinasi.

B) Karakteristik Peserta Didik yang sering menjadi masalah dalam pembelajaran secara umum.

1. Motivasi

Berdasarkan hasil penelitian yang dilakukan oleh Keke T. Aritonang, 2008:10 yaitu minat dan motivasi dapat meningkatkan hasil belajar siswa. Melakukan survey menggunakan kuesioner menunjukkan bahwa mata pelajaran yang diminati siswa adalah keterampilan, olahraga dan kesenian. Faktor utama yang mempengaruhi minat dan motivasi belajar adalah cara mengajar guru, karakter guru, suasana kelas tenang dan nyaman, dan fasilitas belajar yang digunakan.

2. Minat

Berdasarkan penelitian yang dilakukan oleh Siti Nurhasanah, A Sobandi, 2016:1, yaitu Minat Belajar Sebagai Hasil Determinan Hasil Belajar Siswa. Hasil penelitian 
ini mengungkap bahwa semakin tinggi hasil belajar siswa maka semakin tinggi hasil belajar siswa

\section{SIMPULAN}

Karakteristik Peserta Didik yaitu etnik, kultural, status sosial, minat, perkembangan kognitif, pengetahuan awal, gaya belajar, motivasi, perkembangan emosi, perkembangan moral, perkembangan spiritual dan perkembangan motorik. Kendala secara umum pada kegiatan pembelajaran yaitu motivasi dan minat belajar

\section{DAFTAR PUSTAKA}

Eka santika I Wayan. (2000). Pendidikan Karakter pada Pembelajaran Daring. Indonesian Values and Character Education Journal

Miftah Nurul Annisa, Ade Wiliah, Nia Rahmawati. (2020). Pentingnya Pendidikan Karakter pada Anak Sekolah Dasar di Zaman Serba Digital. Bintang: Jurnal Pendidikan dan Sains

Wulandari Ayu Riza, Nila Dewi Nyoman Ayu, Gede Lamopia I Wayan, Wulan Antari Ni Nyoman. (2020). Representasi Peran Guru dalam Pendidikan Karakter Bagi Siswa Sekolah Dasar di SD Negeri 3 Tonja Denpasar

Tria Dewi Aryuna Kusuma,Sudana Dengeng I Nyoman, Hadi Syamsul. (2019).Implementasi Pendidikan Nilai Karakter di Sekolah Dasar melalui Budaya Sekolah. Jurnal Pendidikan: Teori, Penelitian, dan Pengembangan

Sari Kurnia Nurattri, Puspita Dian Linda. (2019). Implementasi Pendidikan Karakter di Sekolah Dasar. Jurnal DIKDAS BANTARA

Munawaroh Isniatun. (2019). Konsep Dasar IImu. Kementrian Pendidikan dan Kebudayaan 